\title{
EFFECT OF DEFICIT IRRIGATION AND RAISED BED ON WHEAT YIELD, WATER PRODUCTIVITY AND WATER SAVING IN NORTH NILE DELTA, EGYPT \\ El-Hadidi, E.M ${ }^{1}$; M. M. Ibrahim ${ }^{2}$; S.A. Abdel-hafez ${ }^{3}$ and

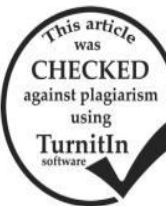 Mona S.M. Eid ${ }^{3}$ \\ 1- Soils Dept., Fac. of Agric. Mansoura Univ. \\ 2- Soil and Water Dept., Fac. of Agric. Tanta Univ. \\ 3- Soils, Water and Environment Res. Institute, A.R.C., Giza.
}

\begin{abstract}
The limitation of water resources and the remarkable increase in population should be forced research workers to find ways for saving water without significant reduction in yield. The objective of this paper is to study the interaction effect of deficit irrigation and raised bed on wheat yield, water productivity and water saving in north Nile delta, Egypt. Two field experiments were conducted at Sakha Agricultural Research Station, Kafr El-Sheikh governorate during the two successive seasons of 2012/2013 and 2013/2014. A split plot design with four replications was used. Irrigation treatments occupied the main plots, while planting methods arranged in subplots. Three planting methods were flat (traditional method, $\left.F_{1}\right)$, bed $70 \mathrm{~cm}$ wide $\left(F_{2}\right)$ and raised bed $140 \mathrm{~cm}$ wide $\left(\mathrm{F}_{3}\right)$. Four deficit irrigation treatments were irrigated every 21 days (farmer treatment, $\left.I_{1}\right)$; the second one after $60 \%\left(I_{2}\right)$, the third one after $70 \%$ $\left(\mathrm{I}_{3}\right)$ and the fourth one after $80 \%\left(\mathrm{I}_{4}\right)$ depletion of available soil moisture (ASMD).

Results showed that mean of amount of irrigation water applied for $\mathrm{DI}_{1}, \mathrm{DI}_{2}, \mathrm{DI}_{3}$ and $\mathrm{DI}_{4}$ were $4759.2,4497.6,3808.8$, and $3360.0 \mathrm{~m}^{3} / \mathrm{ha}$., respectively, and means of water table contribution to $\mathrm{ET}_{\mathrm{c}}$ were 559.2 and $765.6 \mathrm{~m}^{3} /$ ha. for $\mathrm{I}_{3}$ and $\mathrm{I}_{4}$, respectively. Means of irrigation water applied were $4524,4034.4$ and $3763.2 \mathrm{~m}^{3} /$ ha. for $F_{1}, F_{2}$ and $F_{3}$, respectively. $F_{3}$ and $F_{2}$ saved $17 \%$ and $11 \%$ of irrigation water compared with $F_{1}$, respectively. $F_{3}$ significantly increased grain and straw yields by 16 and $18 \%$ compared to $F_{1}$. The interaction between $\mathrm{Dl}_{2}$ and $\mathrm{F}_{3}$ and between $\mathrm{Dl}_{1}$ and $\mathrm{F}_{1}$ resulted in higher grain and straw yields. Means values of water productivity were 5.7, 6.1 and $6.1 \mathrm{~L} . \mathrm{E} / \mathrm{m}^{3}$ correspond to $1.2,1.18$ and $1.5 \mathrm{~kg}$ grain $/ \mathrm{m}^{3}$ water applied for $\mathrm{F} 1, \mathrm{~F} 2$ and F3 respectively .
\end{abstract}

\section{INTRODUCTION}

In Egypt, water is a scarce natural resource, of which the agricultural sector uses about $85 \%$. The country's main source of water is the Nile. Its share of the Nile water is 55.5 billion $\mathrm{m}^{3}$ year ${ }^{-1}$. Egypt receives low rainfall that averages about 1.0 milliard $\mathrm{m}^{3}$ year ${ }^{-1}$ (about 100-200 mm year ${ }^{-1}$ in the northern coastal area in which few winter crops can be grown). El-Sabbagh et al,. (2002) showed that seasonal water consumptive use rates were 39.70, 35.72 and $29.79 \mathrm{~cm}$ for the treatments irrigated at 45,65 and $85 \% \mathrm{SMD}$, respectively. They showed that seasonal water consumptive use increased with the decrease of irrigation intervals. Wheat plants extracted about 80.06 and $19.94 \%$ of its water requirements from the first upper $30 \mathrm{~cm}$ soil surface layer and the second $30 \mathrm{~cm}$ soil layer, respectively, when plants irrigated at $45 \%$ SMD. El-Bably, (1998) found that values of water consumptive use were $38.50,31.56$ and $24.16 \mathrm{~cm}$ for the 50,70 and $90 \%$ soil moisture depletion, 
respectively. Abul-Naas et al. (2000) indicated that wheat plants received four irrigations significantly out yielded those received three, two or one irrigation.

Plant production per given amount of water should be basis for organizing possibilities and invests to increase water profitability (Fereres and Soriano, 2007; Blum, 2009). The necessity of planning to increase the water use efficiency is inevitable from world population growth and water amount.

Deficit irrigation is a water management method in which water will be saved with accepting little yield reduction without any severe damage to the plant (English 1990). Medium stress may be a delay in irrigation for a few days or reduced water consumption in each irrigation, but plant shouldn't encounter severe drought stress at any mentioned situation. El-Sabbagh et al. (2002) showed that maximum water use efficiency was recorded from infrequent irrigation every 35 days. Depths of water table modify greatly the irrigation requirement. When water table is very shallow, soil waterlogging limited the root growth of winter wheat due to the reduced oxygen concentration of the soil (Brisson et al., 2002). In general, water table contribution decreases with the increase of water table depth or irrigation quantity, or the reduction of irrigation spacing (Ayars et al.,2006). When water table is very shallow, irrigation may be eliminated to maximize water table contribution and avoid waterlogging problem.

Bed planting systems have been used in cultivation for centuries. The origin of raised bed cultivation has traditionally been associated with water management issues either by providing opportunities to reduce the impact of excess water in rainfed conditions or to more efficiently deliver irrigation water in high production irrigated systems (Sayre, 2003).

Hobbs et al. (2000) reported that raised-bed planting contributes significantly to the improvement of water distribution and efficiency, and increases fertilizer-use efficiency and reduces weed infestation, lodging and seed rate without sacrificing yield.

The objective of this study is to investigate the mutual effect of deficit irrigation and raised bed technique on wheat and water productivity growing in north delta, Egypt.

\section{MATERIALS AND METHODS}

A field experiment was carried out during the two successive wheat growing seasons of 2012/2013 and 2013/2014 at Crops Water Requirement Research Field, Sakha Agricultural Research Station, Kafr El-Sheikh Governorate. The site is located at $31^{0^{\circ}}-57^{-} / \mathrm{N}$ latitude and $30^{\circ}-57^{-}$longitude with an elevation of about 6 meter above mean sea level. The site represents the conditions and circumstances of North Nile Delta region.

Field capacity, wilting point and bulk density values in the soil profile ( 0 to $60 \mathrm{~cm}$ ) were, in average, $40.6,22.4$ and $1.2 \mathrm{gcm}^{-3}$, respectively. The effective of rainfall received were 82 and $105.4 \mathrm{~mm}$ during the 2012/2013 and 2013/2014 growing seasons, respectively. 
Weather data for the experimental site were obtained from Sakha agrometeorological station are presented in Table 1.

A split plot design with four replications was used. planting methods occupied the main plots, while Irrigation treatments arranged in sub-plots. The planting methods were flat (traditional method, F1), raised bed $70 \mathrm{~cm}$ wide (F2) and $140 \mathrm{~cm}$ wide (F3). Sub plots were devoted to deficit irrigation treatments, the first one was every 21 days (farmer treatment, $\mathrm{DI}_{1}$ ) ; the second one after $60 \%\left(\mathrm{DI}_{2}\right)$, the third one after $70 \%\left(\mathrm{DI}_{3}\right)$ and the fourth one after $80 \%\left(\mathrm{DI}_{4}\right)$ depletion of available soil moisture (ASMD) irrigation. Each individual plot was $7 \mathrm{~m} \times 7.5 \mathrm{~m}=52.5 \mathrm{~m}^{2}$ No. of plots $=4 \times 3 \times 3=36$ plots.

Irrigation scheduling

Irrigation scheduling was based on the percentage depletion of available soil water in the root zone. The available soil water was taken as the difference between root zone water storage at field capacity and permanent wilting point. The maximum allowable depletion (MAD) values of the available soil water were fixed at 60,70 and $80 \%$. Using the data of soil moisture measured by gravimetric measurement, the percentage depletion of available soil water in the effective root zone was estimated by the equation (Martin et al., 1990),

Depletion $\%=100 * \frac{1}{\mathbf{n}} \sum_{1}^{n} \frac{\mathbf{F} \cdot \mathbf{c}-\emptyset}{\mathbf{F} \cdot \mathbf{c}-\mathbf{P w}}$.

Where

$\mathrm{n}$ is the number of sub-divisions of the effective rooting depth used in the soil moisture sampling,

F.c is the soil moisture at field capacity for layer,

$\varnothing$ is the soil moisture in layer and

$\mathrm{Pw}$ is the soil moisture at permanent wilting point.

Control and seasonal water applied (Wa):

The amount of water applied after the attainment of predefined, maximum allowable depletion ( MAD) was calculated as:

$V_{d}=\frac{\text { MAD }(\%) *(F C-W P) * \mathbf{R} *[}{100} \ldots . .($ Martin et al., 1990)

$V_{d}$ is the volume of irrigation water,

$R$ is the effective rooting depth and

$A$ is the surface area of the plot.

The surface area of each plot was $52.5 \mathrm{~m}^{2}$. Each $7.5 \mathrm{~m} \times 7.0 \mathrm{~m}$ plot was made to small basins, which was furrowed and each furrow was fed individually. Measured amounts of water were applied to the furrows using a constructed rectangular weir with a discharge of $0.01654 \mathrm{~m}^{3} \mathrm{sec}^{-1}$ at effective head of $10 \mathrm{~cm}$.

Soil moisture monitoring

Soil samples were taken at sowing, before each irrigation, 2 days after Irrigation or rainfall, 25 days intervals between irrigation and at the time of harvesting, from four layers $(15 \mathrm{~cm}$ each) for each treatment. At each sampling date, duplicate soil samples were taken and were immediately 
packed in tightly loosed cans and transported to the laboratory, then weighed, dried in electrical oven at $105 \mathrm{C}^{\circ}$ for 24 hours, then weighed again and their moisture content were calculated on dry weight basis. Wheat (Triticum aestivum L.) Masr 2 variety was planted in 15 November 2012 and repeated in 2013. All cultural practices in the experimental field were the same as implemented in the area except planting methods and deficit irrigation. The soil samples were collected in $15 \mathrm{~cm}$ increments to $60 \mathrm{~cm}$ depth for analysis (Table, (2) according to Kim (1996). To monitor water table fluctuation, nine observation wells were installed However, amounts and timing were recorded. Irrigation scheduling for other treatments was based on crop evapotranspiration $\left(E T_{c}\right)$.was calculated from the reference evapotranspiration $\mathrm{ET}_{0}$ and the FAO crop coefficients $(\mathrm{Kc}$ ) for wheat (Allen et al., 1998). $\mathrm{ET}_{0}$ was calculated using the Penman-Monteith equation.( cropwat program) $\mathrm{ET}_{\mathrm{c}}$ was computed weekly and irrigation water was added accordingly to maintain the full water requirement for the $F_{0}$ treatment. On average, the number of irrigations was five

Table (1): Sakha agro-meteorological data during 2012/2013and 2013/2014 seasons.

\begin{tabular}{|c|c|c|c|c|c|c|c|c|c|c|c|}
\hline \multirow[t]{2}{*}{ Seasons } & \multirow[t]{2}{*}{ Months } & \multicolumn{3}{|c|}{$\begin{array}{c}\text { Air temperature } \\
\left({ }^{\circ} \mathrm{C}\right)\end{array}$} & \multicolumn{3}{|c|}{$\begin{array}{c}\text { Relative humidity } \\
(\%)\end{array}$} & \multirow{2}{*}{$\begin{array}{l}\text { Wind } \\
\text { speed } \\
\text { km d }^{-1} \\
\end{array}$} & \multirow{2}{*}{$\begin{array}{c}\text { Pan } \\
\text { evaporation } \\
\text { mm d }^{-1}\end{array}$} & \multirow{2}{*}{$\begin{array}{c}\text { Rain, } \\
\mathrm{mm} / \mathrm{mon} \\
.\end{array}$} & \multirow{2}{*}{$\begin{array}{c}\text { Effective } \\
\text { rain, } \\
\mathrm{mm} / \mathrm{mon} \text {. }\end{array}$} \\
\hline & & Max. & Min. & Mean & Max. & Min. & Mean & & & & \\
\hline \multirow{7}{*}{$2012 / 2013$} & Nov & 25.3 & 15.4 & 20.35 & 89.2 & 61.8 & 75.2 & 56.9 & 1.87 & 29.0 & 18.0 \\
\hline & Dec. & 21.3 & 10.5 & 15.9 & 84.7 & 60.7 & 72.7 & 62.9 & 2.2 & 13.2 & 6.2 \\
\hline & Jan. & 19.2 & 7.6 & 13.4 & 90.9 & 65.4 & 78.15 & 46.3 & 1.9 & 78.74 & 55.3 \\
\hline & Feb. & 20.8 & 8.9 & 14.85 & 90.2 & 63.8 & 77 & 61.1 & 2.9 & - & \\
\hline & Mar. & 24.4 & 12.4 & 18.4 & 79.5 & 50.9 & 65.2 & 89.2 & 4.4 & - & \\
\hline & Apr . & 26.0 & 15.8 & 20.9 & 74.2 & 43.9 & 59.05 & 96.3 & 5.0 & 8.4 & 2.6 \\
\hline & May & 31.4 & 21.8 & 26.6 & 75.0 & 45.7 & 60.35 & 102.6 & 6.1 & - & \\
\hline Total & & & & & & & & & & & 82.0 \\
\hline \multirow{7}{*}{$2013 / 2014$} & Nov & 25.3 & 15.1 & 20.2 & 87.0 & 64.4 & 75.7 & 68.7 & 2.2 & ---- & \\
\hline & Dec. & 19.6 & 8.5 & 14.05 & 92.0 & 67.6 & 79.8 & 52.6 & 4.4 & 81.9 & 57.7 \\
\hline & Jan. & 20.3 & 7.5 & 13.9 & 93.6 & 70.5 & 82.05 & 46.6 & 1.6 & 20.7 & 11.8 \\
\hline & Feb. & 20.6 & 8.1 & 14.35 & 91.9 & 67.1 & 79.5 & 66.3 & 2.5 & 16.5 & 8.6 \\
\hline & Mar. & 22.9 & 11.7 & 17.3 & 86.1 & 56.8 & 71.45 & 82.8 & 3.1 & 26.2 & 15.9 \\
\hline & Apr. & 27.5 & 15.5 & 21.5 & 81.8 & 49.8 & 65.8 & 92.8 & 4.9 & 20.2 & 11.4 \\
\hline & May & 30.4 & 19.5 & 24.95 & 77.2 & 48.6 & 62.9 & 98.8 & 5.8 & - & \\
\hline Total & & & & & & & & & & & 105.4 \\
\hline
\end{tabular}

Effective Precipitation $(\mathrm{mm})=($ Rain -5$) \times 0.75$

\section{Crop water use:}

Crop water use is directly related to ET. The crop's water use can be determined by multiplying the reference ETo by a crop coefficient (Kc). The crop coefficient adjusts the calculated reference ETo to obtain the crop evapotranspiration ETc. Different crops will have a different crop coefficient and resulting water use.

\section{$\mathrm{ETc}=\mathrm{ETO} \times \mathrm{Kc}$}

Where $E T o=$ calculated reference ET for grass $(\mathrm{mm})$

available from www.farmwest.com

$\mathrm{Kc}=$ crop coefficient

$\mathrm{ETC}=$ crop evapotranspiration or crop water use $(\mathrm{mm})$ 


\section{Crop coefficient Kc}

Values of the Kc were quoted from FAO ( Allen et.al., 1998). The four distinct growing stages of growing period are initial (35 days), crop establishment (60 days), mid-season (70 days) and late season (40 days). The corresponding values are $0.4,0.75,1.05$, and 0.6 respectively. The length of growing stages of wheat identified with respect to (Allen, et al., 1998 )

Table (2): The mean values of some soil physical properties and some water constants of the experimental site before cultivation in the two growing seasons

\begin{tabular}{|c|c|c|c|c|c|c|c|c|c|c|c|c|c|}
\hline \multirow{2}{*}{$\begin{array}{l}\text { Soil } \\
\text { depth } \\
\text { (cm) }\end{array}$} & \begin{tabular}{|c|} 
Bulk \\
density
\end{tabular} & \multicolumn{2}{|c|}{ F.C } & \multicolumn{2}{|c|}{ P.W.P } & \multicolumn{2}{|c|}{ A.W } & \multicolumn{2}{|c|}{$\begin{array}{c}60 \% \\
\text { depletion }\end{array}$} & \multicolumn{2}{|c|}{$\begin{array}{c}70 \% \\
\text { depletion }\end{array}$} & \multicolumn{2}{|c|}{$\begin{array}{c}80 \% \\
\text { depletion }\end{array}$} \\
\hline & $\mathrm{Mg} / \mathrm{m}^{3}$ & $\%$ & $\mathbf{m m}$ & $\%$ & $\mathrm{~mm}$ & $\%$ & $\mathrm{~mm}$ & $\%$ & $\mathbf{m m}$ & $\%$ & $\mathrm{~mm}$ & $\%$ & $\mathrm{~mm}$ \\
\hline $0-15$ & \begin{tabular}{|l}
1.22 \\
\end{tabular} & 47.0 & 86.0 & 25.3 & 46.2 & 21.7 & 38.8 & 13.02 & 23.2 & 15.19 & 27.16 & 17.36 & 31.04 \\
\hline $15-30$ & 1.24 & 39.0 & 72.5 & 21.8 & 40.5 & 17.2 & 32.0 & 10.32 & 19.2 & 12.04 & 22.4 & 13.76 & 25.6 \\
\hline $30-45$ & 1.30 & 38.0 & 74.1 & 21.9 & 42.7 & 16.1 & 31.4 & 9.66 & 18.84 & 11.27 & 21.98 & 12.88 & 25.12 \\
\hline $45-60$ & 1.20 & 38.5 & 69.1 & 20.8 & 37.4 & 17.7 & $\begin{array}{l}31.7 \\
\end{array}$ & 10.62 & 19.02 & 12.39 & 22.19 & 14.16 & 25.36 \\
\hline
\end{tabular}

\section{Water consumptive use (CU):}

Water consumptive use (CU) or crop evapotranspiration (ETC) of wheat was determined directly as soil moisture depletion(SMD) using the following equation (Hansen et al., 1980).

$$
\mathrm{Cu}=\mathrm{SMD}=\sum_{i=1}^{1=4} \mathrm{D}_{1} \times \mathrm{D}_{\mathrm{b} 1} \times \frac{\mathrm{PW}_{2}-\mathrm{PW}_{1}}{100}
$$

Where:

$\mathrm{Cu}=$ Water consumptive use $(\mathrm{cm})$ in the effective root zone $(60 \mathrm{~cm})$.

$\mathrm{D}_{1} \quad=$ Soil layer depth $(15 \mathrm{~cm}$ each).

$D_{b 1}=$ Soil bulk density, $\left(\mathrm{Mg} / \mathrm{m}^{3}\right)$ for this depth.

$\mathrm{PW}_{1}=$ Soil moisture percentage before irrigation (on mass basis, \%).

$\mathrm{PW}_{2}=$ Soil moisture percentage, 48 hours after irrigation (on mass basis, \%)..

I = Number of soil layers each $(15 \mathrm{~cm})$ depth.

The summation of $\mathrm{Cu}$ between each two irrigation from planting up the harvest give the seasonal crop water consumptive use. The consumptive use values was corrected for the time days from irrigation event to the time of sampling after irrigation using the daily average of the considered period.

\section{Contribution of the ground water table (S):}

Water movement by capillary rise from water table into active plant root zone is recognized as an important supplementary water resource for irrigation. The contribution of groundwater as percentage of the consumptive use was calculated as follow: 
Where :

$$
\mathrm{S}=\left[\left(\mathrm{ET}_{\mathrm{c}}-\mathrm{SMD}\right)\right.
$$

$\mathrm{ET}_{\mathrm{c}}=$ Crop evapotranspiration $=\mathrm{ET}_{0} \times \mathrm{K}_{\mathrm{c}}$

SMD = Soil moisture depletion.

Reference evapotranspiration ( $\mathrm{ET}_{0}$ ):

CROPWAT for windows is a program that uses the FAO (1992)

Penman-Monteith methods for calculating reference crop evapotranspiration.

These estimates are used in crop water requirements and irrigation scheduling calculations. The methods supersede the older FAO 24 procedures published in 1977 which are no longer recommended as they overestimate evapotranspiration.

Fluctuation of ground water table:

In order to establish the diagram of ground water table fluctuation during the growing seasons under wheat crop, a nine observation wells were installed along different treatment. Perforated plastic tube with each observation well was two inches in diameter and two meter long. Daily reading of ground water table was recorded by the aid of a metallic sounder that fixed in a sealed tape to measure the water table depth.

Yield and yield components:

straw yield, biomass yield and wheat grain yield $\mathrm{kg} \mathrm{ha}^{-1}$ at maturity were determined from central area of each subplot to avoid any effect and recorded in the two growing seasons. The grains were separated from the straw, and the grains were weighed. Grain yield was calculated based on the adjustment to grain moisture content of $140 \mathrm{~g} \mathrm{~kg}^{-1}$. Biomass yield express grain plus straw yields.

Water measurements.

Water productivity (WP) was calculated according to Molden, (1997)

WP $\left(\mathrm{kg} \mathrm{m}^{-3}\right.$ or $\$ \mathrm{~m}^{-3}=$ Output derived from water use $\left(\mathrm{kg} / \mathrm{m}^{3}\right.$ or $\$ / \mathrm{m}^{3}$

Application efficiency (Ea):

$$
\text { Water input }\left(\mathrm{m}^{3}\right)
$$

This parameter is so-called consumptive use efficiency (Ecu) and computed according to Doorenbos and Pruitt (1975) as:

where:

$$
\mathrm{Ea}=(\mathrm{CU} / \mathrm{Wa})^{*} 100
$$

$\mathrm{Wa}=$ Water applied, and

$\mathrm{CU}=$ Crop evapotranspiration or crop consumptive use.

Measurements of Yield and Water productivity:

The reductions in yield and water saving were calculated from the following equations:

$$
\begin{aligned}
& \text { reduction in yield }=100-\left(\frac{\text { yield of } I 2 \text { or } I 3}{y i \text { II } \text { of } I 1}\right) \times 100 \\
& \text { Water saving }=100-\left(\frac{\text { water consumption of } I 2 \text { or } I 3}{\text { water cEnsumption of } I 1}\right) \times 100
\end{aligned}
$$




\section{RESULTS AND DISCUSSION}

\section{Fluctuation of water table depth during the growing seasons:}

Seasonal average of maximum and minimum values of water table depth, for each observation well, under each treatment. during the two growing seasons were given in table (3). The obtained data showed that the depth of water table reached the lowest value immediately before irrigation. While the maximum water depth reached at 2 days after irrigation. Following irrigation, the water table decreased gradually in between irrigation. Maximum values of water table depth varied between 67 and $80 \mathrm{~cm}$ in the first and second seasons respectively. The corresponding values of the minimum water table depth were 95 and $123.5 \mathrm{~cm}$. the fluctuation of the water table depends of the deficit irrigation and the distance from both the irrigation canal and in the north and main surface drain in the south of the experiment area. The absolute values of both minimum and maximum depth of water table increased directly with increasing deficit irrigation and as much as close to the main open drain in the site. So, by increase the deficit irrigation, more water being allowed to be depleted by growing plants and consequently further through fall could be obtained. This technique of elongate deficit irrigation in Nile Delta have the advantage of proper aeration in the effective root zone, minimizing the water logging hazard in the area and save a reasonable amount of irrigation water.

\section{Seasonal water applied (Wa)}

Under the conditions of the present study, the seasonal water applied (Wa) consists of the three components; irrigation water (IW), rainfall (R) and contribution of water table (S). Wheat as a winter crop rainfall were 344 and $442 \mathrm{~mm}$ in the first and second season respectively. Water applied decreased by increasing maximum allowable depletion.

Water consumptive use (CU).

The obtained results in Table (4) show that seasonal CU values were greatly affected by deficit irrigation, where CU values decreased with increasing the irrigation intervals. Seasonal average values of $\mathrm{CU}$ during the two seasons. These results indicate that consumptive use decreased as the available soil moisture decreased in the root zone. These results are in agreement with those obtained by El-Tantawy et al., (2007)

\section{Irrigation water (IW):}

As shown in table(5) the total number of irrigation events were $5,5,4$ and 3 for $\mathrm{DI}_{1}, \mathrm{DI}_{2}, \mathrm{DI}_{3}$ and $\mathrm{DI}_{4}$ respectively, including sowing irrigation. Amounts of irrigation water (IW) throughout the two seasons for different treatments, are tabulated in Table (3). Mean values of irrigation water were 4831.2, 4663.2, 3856.8 and $3328.8 \mathrm{~m}^{3} / \mathrm{ha}$. for $\mathrm{Dl}_{1}, \mathrm{Dl}_{2}, \mathrm{Dl}_{3}$ and $\mathrm{DI}_{4}$ respectively as the deficit irrigation treatments in the first season while it was , 4687.2, 4332.0, 3758.4 and $3228.0 \mathrm{~m}^{3} / \mathrm{ha}$. In the second season respectively. Irrigation water for $\mathrm{I}_{4}$ treatment was the lowest, and the amount for $\mathrm{DI}_{1}$ treatment was the highest. These data indicate that using irrigation at depletion $80 \%$ from available water ( $\mathrm{DI}_{4}$ irrigation treatment) saved water by about $31.1 \%\left(617 \mathrm{~m}^{3}\right)$ compared with irrigation treatment $\mathrm{I}_{1}$ (the conventional 
irrigation), while wide furrow treatments Mean values of irrigation water were 4676.2, 4063.2 and $3775.2 \mathrm{~m}^{3} \mathrm{ha}^{-1}$. for $F_{1}, F_{72}$ and $F_{3}$ in the first season while it was $4250.4,4003.2$ and $3748.8 \mathrm{~m}^{3} \mathrm{ha}^{-1}$. In the second season respectively. Also data show that using raised bed $\left(\mathrm{F}_{3}\right)$ saved water by about $19 \%\left(900 \mathrm{~m}^{3} / \mathrm{ha}\right.$..) in the first season while the second season was $14 \%$ $\left(621.6 \mathrm{~m}^{3} / \mathrm{ha}\right)$ Compared with $\left(\mathrm{F}_{1}\right)$.

Table (3): Maximum, Minimum and mean values of water table depth $\mathrm{cm}$. during the two growing seasons 2012/2013 and 2013/2014.

\begin{tabular}{|c|c|c|c|c|c|c|c|c|}
\hline \multirow{2}{*}{$\begin{array}{l}\text { Observation } \\
\text { well }\end{array}$} & \multirow{2}{*}{\multicolumn{2}{|c|}{ Treat. }} & \multicolumn{3}{|c|}{ Season $2012 / 2013$} & \multicolumn{3}{|c|}{ Season 2013/2014 } \\
\hline & & & Maxi & Mini. & Mean & Maxi & . Mini. & Mean \\
\hline 1 & \multirow{4}{*}{ 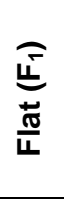 } & $\mathrm{DI}_{1}$ & 67 & 87 & 96.8 & 80.4 & 113.1 & 96.75 \\
\hline 2 & & $\mathrm{DI}_{2}$ & 75 & 88 & 102.2 & 90.0 & 114.4 & 102.20 \\
\hline 3 & & $\mathrm{DI}_{3}$ & 78 & 82 & 100.1 & 93.6 & 106.6 & 100.10 \\
\hline 4 & & $\mathrm{DI}_{4}$ & 83 & 81 & 102.5 & 99.6 & 105.3 & 102.45 \\
\hline 5 & \multirow{4}{*}{ 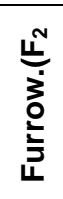 } & $\mathrm{DI}_{1}$ & 70 & 80 & 94.0 & 84.0 & 104 & 94.00 \\
\hline 6 & & $\mathrm{DI}_{2}$ & 75 & 84 & 99.6 & 90.0 & 109.2 & 99.60 \\
\hline 6 & & $\mathrm{DI}_{3}$ & 80 & 84 & 102.6 & 96.0 & 109.2 & 102.60 \\
\hline 7 & & $\mathrm{DI}_{4}$ & 83 & 89 & 107.7 & 99.6 & 115.7 & 107.65 \\
\hline 8 & \multirow{4}{*}{ 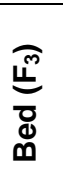 } & $\mathrm{DI}_{1}$ & 72 & 85 & 98.5 & 86.4 & 110.5 & 98.45 \\
\hline 9 & & $\mathrm{DI}_{2}$ & 75 & 89 & 102.9 & 90.0 & 115.7 & 102.85 \\
\hline 10 & & $\mathrm{DI}_{3}$ & 80 & 92 & 107.8 & 96.0 & 119.6 & 107.80 \\
\hline 11 & & $\mathrm{DI}_{4}$ & 85 & 95 & 112.8 & 102.0 & 123.5 & 112.75 \\
\hline
\end{tabular}

\section{Contribution of water table (\%):}

Values of contribution of water table to crop evapotranspiration during the two seasons are given in Table (6).

Data revealed that by increasing irrigation water, less value was obtained. For the maximum irrigation water (treatment $\mathrm{DI}_{1}$ and $\mathrm{DI}_{2}$ ) there was no contribution from water table. For the other treatments $\left(I_{3}\right.$ and $\left.I_{4}\right)$ average values of contribution are 211 and $325 \mathrm{~m}^{3}$ for first season while it was 255 and $313 \mathrm{~m}^{3}$ for second season respectively. This slight contribution of water table was occurred during about the middle of the season. This finding indicated that by increasing the applied water in the short irrigation interval of (treatment $\mathrm{DI}_{1}$ and $\mathrm{DI}_{2}$ ) almost no contribution but the feeding to groundwater table took the same direction with that applied depth. Also, this feeding may be from the neighboring fields. The reason for the non contribution from water table during other periods may be attributed to the less water consumed by plants at both early and ripening stage (Eid, 1994). 
J.Soil Sci. and Agric. Eng., Mansoura Univ., Vol. 6 (7), July, 2015

4

853 
El-Hadidi, E.M. et al.

$5-6$ 


\section{Grain yield $\left(\mathrm{kgha}^{-1}\right)$}

Means of grain yield in $\mathrm{kg}$./ha. of wheat as affected by deficit irrigation and wide furrow regime in both seasons of study are shown in Table $(7,8)$ .deficit irrigation regime significantly influenced grain yield per ha. In both seasons, generally, grain yield was highest under 12 water regime as compared with the other three regimes. This occurred in both seasons. The mean grain yields for the two seasons obtained by $11,12,13$ and 14 water regimes are $6741.336,7231.992,6381.336$ and $5882.664 \mathrm{~kg}$ ha-1 in the first season while it was $7399.99,7954.66,7020.00$ and $6469.34 \mathrm{~kg}$ ha- 1 . in the second season .respectively.(Table 6,7 ).

\section{Effect of raised bed:}

Regarding the effect of raised bed treatments, grain yield was greater with $F_{3}$ treatment than the other two raised bed treatments. This occurred under each of the deficit irrigation regimes since the interaction between the raised bed treatment and deficit irrigation was significant (Table 7,8). Mean yields for the two seasons due to raised bed treatments of $F_{1}, F_{2}$ and $F_{3}$ are $6304.8,6306$ and $7237.9 .14 \mathrm{~kg} / \mathrm{ha}$. in the first season while it was, 6735.00 , 6936.00 and $7962.00 \mathrm{~kg} / \mathrm{ha}$. .in the second season .respectively. Thus the $F_{3}$ treatment gave the highest yield. $F_{3}$ significantly increased grain and straw yields by 16 and $18 \%$ compared to $F_{1}$..

The highest grain yield was obtained by $\mathrm{I}_{2} \mathrm{~F}_{3}$ treatment which gave 8119.2 and $8935.99 \mathrm{~kg} / \mathrm{ha}$. The lowest yield was obtained by the $\mathrm{I}_{4} \mathrm{~F}_{1}$ treatment which gave 5508.0 and $6055.99 \mathrm{~kg} / \mathrm{ha}$ in the first and second season respectively .

\section{Deficit irrigation (DI) and water productivity (WP)}

When water supplies are limiting, the farmer's goal should be to maximize net income per unit water used rather than per land unit. Recently, emphasis has been placed on the concept of water productivity, defined here either as the yield or net income per unit of water used in ET.table 9-10 show that WP increases under DI, relative to its value under full irrigation, as shown experimentally for many crops. There are several reasons for the increase in WP under DI. Small irrigation amounts increase crop ET, more or less linearly up to a point where the relationship becomes curvilinear because part of the water applied is not used in ET and is lost. At one point, yield reaches its maximum value and additional amounts of irrigation do not increase it any further. The location of that point is not easily defined and thus, when water is not limited or is cheap, irrigation is applied in excess to avoid the risk of a yield penalty. The amount of water needed to ensure maximum yields depends on the uniformity of irrigation. Under low uniformity, irrigation efficiency decreases and water losses are high. Because water cannot be applied with perfect uniformity, variations in applied water over the field are ranked and plotted against the fraction of the area. The depth of water is normalized against the required depth. Generalized relationships between applied irrigation water, ET, and crop grain yield. In addition to the factors associated with the disposition of irrigation water, WP is also affected by the yield response to irrigation. 
El-Hadidi, E.M. et al.

$7-8$ 
Yield responses to irrigation and to ET deficits have been studied empirically for decades. It turned out that it is not only biomass production that is linearly related to transpiration, but the yield of many crops is also linearly related to ET.

The design of a DI program may must be based on knowledge of this response but the exact characteristics of the response function are not known in advance. Also, the response varies with location, stress patterns, cultivar, planting dates, and other factors. In particular, many crops have different sensitivities to water stress at various stages of development, and the DI program me must be designed to manage the stress so that yield decline is minimized. However, when the yield decline, in relative terms, is less than the ET decrease, WP under DI increases relative to that under full irrigation. Nevertheless, from the standpoint of the farmer, the objective is not WP, but net income, low risk, and other issues related to the sustainability of irrigation are more important. Knowledge of the crop response to DI is essential to achieve such objectives when water is limited.

\section{Consumptive use efficiency (Ecu):}

Consumptive use efficiency reflects the capacity of roots to utilize the moisture stored in the soil between irrigation intervals. Data in Table (8) show that the highest value of $\mathrm{Ecu}$ is 74 and $72.3 \%\left(\mathrm{DI}_{4}\right)$ in the first and second season respectively. So, the decreasing the dominator of water applied the increasing in Ecu. Such results are agreed with those reported by Doorenbos et al.(1979) who stated that the consumptive use efficiency increased with the increase of consumptive use and with the decrease in water applied.

The use of the RB technique increased water productivity from around $1.06 \mathrm{~kg} / \mathrm{m}^{3}$ for the farmers' usual water management practice to 1.67 $\mathrm{kg} \mathrm{m}^{-3}$. In general, the relationship between water productivity and yield was significant with a coefficient of determination $\left(R^{2}\right)$.

Our data showed that, for similar amounts of applied water, raised bed (RB) gave in most cases higher WP than DI. Hobbs et al. (2000) demonstrated that RB planting contributed significantly to improved water distribution and efficiency, increased fertilizer use efficiency and reduced weed infestation, lodging and seed rate without sacrificing yield. These values varied from about 2.0 Egyptian Pounds $/ \mathrm{m}^{3}$ under high water application (FT and FWR treatments) to 2.8 Egyptian Pounds $/ \mathrm{m}^{3}$ for the water saving methods (DI and RB treatments) in wheat 
El-Hadidi, E.M. et al. 
J.Soil Sci. and Agric. Eng., Mansoura Univ., Vol. 6 (7), July, 2015

9

859 
Table (10): Water productivity L.E $/ \mathrm{m}^{3}$ affected by deficit irrigation and wide furrow during the two growing seasons

\begin{tabular}{|c|c|c|c|c|c|c|c|c|}
\hline \multirow{2}{*}{ 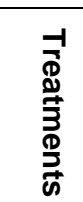 } & \multicolumn{4}{|c|}{ WP 2012/2013 } & \multicolumn{4}{|c|}{ WP 2013/2014 } \\
\hline & $\begin{array}{l}\text { Flat } \\
\text { (F1) }\end{array}$ & $\begin{array}{c}\text { Furrow } \\
\text { ( F2) }\end{array}$ & Bed (F3) & I-Mean & $\begin{array}{l}\text { Flat } \\
\text { (F1) }\end{array}$ & $\begin{array}{c}\text { Furrow } \\
\text { ( F2) }\end{array}$ & $\begin{array}{l}\text { Bed } \\
\text { (F3) }\end{array}$ & I-Mean \\
\hline $\mathrm{DI}_{1}$ & 5.45 & 6.21 & 6.12 & 6.11 & 5.75 & 6.82 & 5.95 & 6.17 \\
\hline $\mathrm{DI}_{2}$ & 5.76 & 6.49 & 5.14 & 5.80 & 6.84 & 7.03 & 6.89 & 6.92 \\
\hline $\mathrm{DI}_{3}$ & 5.15 & 5.80 & 6.36 & 5.77 & 5.88 & 5.95 & 6.11 & 5.98 \\
\hline $\mathrm{DI}_{4}$ & 5.03 & 5.30 & 6.01 & 5.45 & 5.87 & 5.51 & 5.80 & 5.73 \\
\hline $\begin{array}{l}\text { F- } \\
\text { Mean }\end{array}$ & 5.35 & 5.95 & 6.04 & & 6.09 & 6.33 & 6.19 & \\
\hline
\end{tabular}

\section{CONCLUSION}

From this study, we can conclude that DI and the use of the RB technique reduce irrigation water application and improve water productivity, if water saving is a major issue, then, some yield reduction must be accepted as shown by the trade-off in this study between water saving and yield loss. An alternative would be to introduce the wide-furrow (RB) technology because, according to our study and others, it did not involve any yield reduction

\section{REFERENCES}

Abul-Naas, A.A.; S.E. Esmail; S.M. Abdel Aal and H.E. Ali, 2000. Drought resistance in some tritical genotypes in comparison with wheat and barley. Menufiya J. Agric. Res. 25(1): 55-80.

Allen RG, LS.Pereira, D.Raes, and M.Smith (1998). Crop evapotranspiration: guidelines for computing crop water requirements. FAO Irrigation and drainage paper No. 56. Rome, Italy: FAO.

Ayars JE, Christen EW, Soppe RW, Meyer WS (2006) The resource potential of in-situ shallow ground water use in irrigated agriculture: a review. Irrigation Sci 24: 147-160.

Blum, A., (2009). Effective use of water (EUW) and not water-use efficiency (WUE) is the target of crop yield improvement under drought stress. Field Crops Research, 112:119-123.

Brisson N, Rebisre B, Zimmer D, Renault P (2002) Response of the root system of a winter wheat crop to waterlogging.Plant Soil 243: 43-55.

Doorenbos J.; A. H. Kassam; C.L. M. Bentvelson and V. Broncheid (1978). Yield response to water. FAO Irrigation and drainage Paper, No. 33 Rome.

Doorenbos, J. and W. O. Pruitt (1975). Crop water requirements. FAO Irrigation and drainage Paper, No. 24 Rome. 
Doorenbos, J.; A. H. Kassam; C.L. M. Bentvelson and V. Broncheid (1979). Yield response to water. FAO Irrigation and drainage Paper, No. 33 Rome.

Eid, S.M.I. (1994): Some water applications and yield of sugar beet and sunflower crops as influenced by frequency and amounts of irrigation water in Northern Delta . M.Sc. thesis, Fac. Agric Tanta Univ.

El-Bably, A.Z. (1998). Studies of some stress conditions affecting the growth and yield of wheat (T. aestivum L.). Ph.D. Thesis, Agron. Dept., Fac. of Agric., Tanta Univ., Kafr El-Sheikh, Egypt.

El-Sabbagh, S.A.; S.A. Abd El-Hafez; A.Z. El-Bably and E.I. Abou-Ahmed, 2002. Wheat productivity as influenced by soil moisture level sand foliar spray with some organic acids. Minufiya J. Agric. Res. 27(2): 425-438.

El-Tantawy M. M, S. A. Ouda, and F. A. Khalil(2007) Irrigation Scheduling for Maize Grown under Middle Egypt Conditions Research Journal of Agriculture and Biological Sciences, 3(5): 456-462

English, M. J. (1990). Deficit irrigation. I. Analytical framework. Journal of Irrigation and Drainage Engineering, 116: 399-412.

Farré. I.and J.M .Faci (2006). Comparative response of maize (Zea mays L.) and sorghum (Sorghum bicolor L. Moench) to deficit irrigation in a Mediterranean environment. Agric. Water Manage., 83: 135-143.

Fereres, E. and M. A. Soriano, (2007). Deficit irrigation for reducing agricultural water use. Journal of Experimental Botany, 58: 147-159.

Hansen, V.W.; D.W. Israelsen and D.E. Stringharm (1980). Irrigation Principle and Practices, 4th ed. Johns Wiley \& Sons., New York.

Hobbs PR, Y. Singh, G.S. Giri, J.G. Lauren and J.M. Duxbury (2000). Direct seeding and reduced tillage options in the rice-wheat systems of the Indo-Gangetic plains of South Asia. IRRI workshop, Bangkok, Thailand, pp. 25-26.

Kim ,H.Tan (1996). Soil Sampling, Preparation and analysis. Marcel Dekker, Inc. New York, $391 \mathrm{p}$.

Majumdar, D.K. and N. Roychoudhury, (1981). Response to irrigation, nitrogen levels and seed treatment with ascorbic acid of wheat grown under shallow water table, Indian Agriculturist. 25(4): 241-247.

Molden, D., (1997). Accounting for water use and productivity. SWIM Paper 1. International Irrigation Management Institute, Colombo, Sri Lanka.

Sayre, K.D.( 2003). Raised-Bed Cultivation. Encyclopedia of Soil Science. 1-4.

Martin, D.L., Stegman, E.C., Freres, E., (1990). Irrigation scheduling principals. In:Management of farm irrigation systems. Hoffman, G.L., Howell, T.A.,Solomon, K.H. (eds.). ASAE Monograph. pp. 155-372. 
تأثير نقص الرى والزراعة على مصـاطب على كل من محصول القمبح وانتاجية

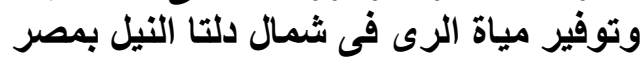

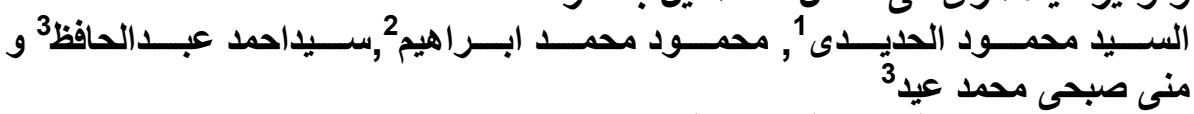

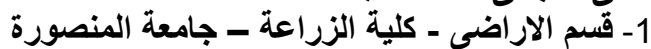

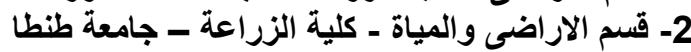
3- معهد بحوث الاراضى والمياة والبيئة ــ مركز البحوث الزئة الزراعية ــ الجيزة- مصر

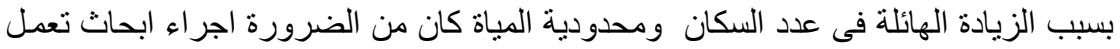

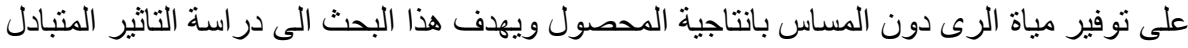

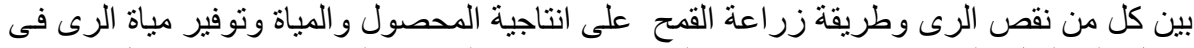

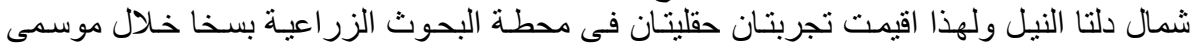

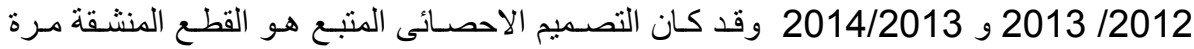

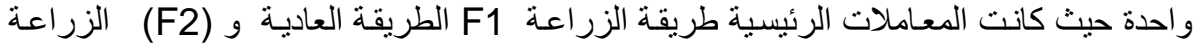

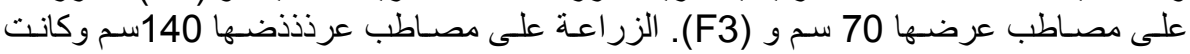

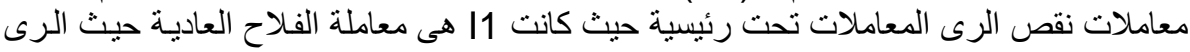

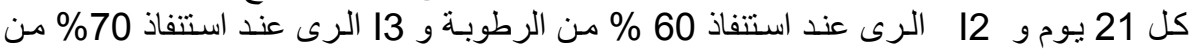

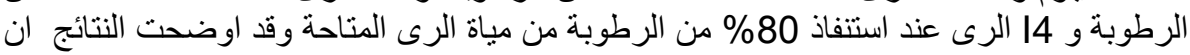

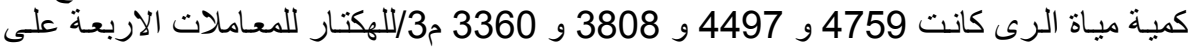

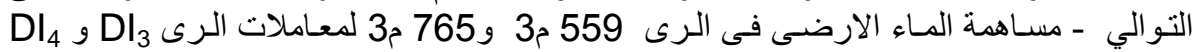

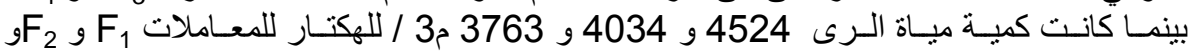

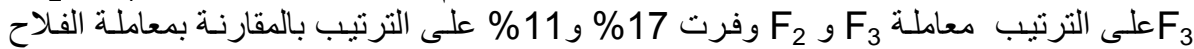

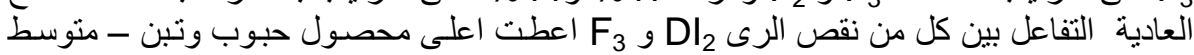

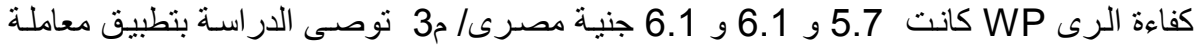


J.Soil Sci. and Agric. Eng., Mansoura Univ., Vol. 6 (7): 845 - 862, 2015 
Table (4): Seasonal irrigation (IW), rainfall (R), contribution from water table (S), seasonal water applied (Wa)and contribution of ground water as percentage (\%) for wheat in the two seasons

\begin{tabular}{|c|c|c|c|c|c|c|c|c|c|c|c|c|c|}
\hline \multirow{3}{*}{\multicolumn{2}{|c|}{ Treat. }} & \multicolumn{6}{|c|}{ Season $2012 / 2013$} & \multicolumn{6}{|c|}{ Season $2013 / 2014$} \\
\hline & & \multicolumn{2}{|c|}{ IW } & \multirow[b]{2}{*}{$\mathbf{R}$} & \multirow{2}{*}{$\mathbf{s}$} & \multirow{2}{*}{ Wa } & \multirow{2}{*}{$\%$} & \multicolumn{2}{|c|}{ IW } & \multirow{2}{*}{$\mathbf{R}$} & \multirow{2}{*}{$\mathbf{s}$} & \multirow{2}{*}{ Wa } & \multirow{2}{*}{$\%$} \\
\hline & & No. & $\mathrm{M}^{3}$ & & & & & No. & $\mathrm{M}^{3}$ & & & & \\
\hline \multirow{4}{*}{$\begin{array}{l}\frac{\pi}{N} \\
\stackrel{M}{=}\end{array}$} & $\mathrm{DI}_{1}$ & 5 & 5400.0 & 825.6 & 0 & 6226 & 0.00 & 5 & 5400.0 & 1060 & 0 & 6461 & 0.00 \\
\hline & $\mathrm{DI}_{2}$ & 5 & 5136.0 & 825.6 & 0 & 5962 & 0.00 & 5 & 4411.2 & 1060 & 0 & 5472 & 0.00 \\
\hline & $\mathrm{DI}_{3}$ & 4 & 4392.0 & 825.6 & 367.2 & 5585 & 8.36 & 4 & 3907.2 & 1060 & 439.2 & 5407 & 11.24 \\
\hline & $\mathrm{DI}_{4}$ & 3 & 3768.0 & 825.6 & 662.4 & 5256 & 17.58 & 3 & 3763.2 & 1060 & 604.8 & 4949 & 16.07 \\
\hline \multirow{4}{*}{ 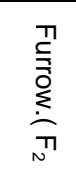 } & $\mathrm{DI}_{1}$ & 5 & 4608.0 & 825.6 & 0 & 5434 & 0.00 & 5 & 4368.0 & 1060 & 0 & 5429 & 0.00 \\
\hline & $\mathrm{DI}_{2}$ & 5 & 4488.0 & 825.6 & 0 & 5314 & 0.00 & 5 & 4312.8 & 1060 & 0 & 5374 & 0.00 \\
\hline & $\mathrm{DI}_{3}$ & 4 & 3696.0 & 825.6 & 472.8 & 4994 & 12.79 & 4 & 3816.0 & 1060 & 472.8 & 5350 & 12.39 \\
\hline & $\mathrm{DI}_{4}$ & 3 & 3456.0 & 825.6 & 655.2 & 4937 & 18.96 & 3 & 3520.8 & 1060 & 655.2 & 5237 & 18.61 \\
\hline \multirow{4}{*}{ 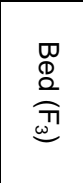 } & $\mathrm{DI}_{1}$ & 5 & 4488.0 & 825.6 & 0 & 5314 & 0.00 & 5 & 4296.0 & 1060 & 0 & 5357 & 0.00 \\
\hline & $\mathrm{DI}_{2}$ & 5 & 4368.0 & 825.6 & 0 & 5194 & 0.00 & 5 & 4272.0 & 1060 & 0 & 5333 & 0.00 \\
\hline & $\mathrm{DI}_{3}$ & 4 & 3480.0 & 825.6 & 681.6 & 4987 & 19.59 & 4 & 3552.0 & 1060 & 921.6 & 5534 & 25.95 \\
\hline & $\mathrm{DI}_{4}$ & 3 & 2760.0 & 825.6 & 1020.0 & 4606 & 36.96 & 3 & 2880.0 & 1060 & 996.0 & 4937 & 34.58 \\
\hline
\end{tabular}


Table ( 5 ) amount of irrigation water in $\mathrm{m}^{3} \mathrm{ha}^{-1}$. For wheat crop during the two growing seasons 2012/2013 and 2013/2014

\begin{tabular}{|c|c|c|c|c|c|c|c|c|}
\hline \multirow[b]{2}{*}{ Treatments } & \multicolumn{4}{|c|}{ season $2012 / 2013$} & \multicolumn{4}{|c|}{ season $2013 / 2014$} \\
\hline & Flat (F1) & furro (F2) & Bed (F3) & I - Mean & Flat (F1) & $\begin{array}{c}\text { furrow } \\
\text { (F2) }\end{array}$ & Bed (F3) & I - Mean \\
\hline DI1 & 5400.0 & 4608.0 & 4488 & 4831.2 & 5400.0 & 4368.0 & 4296.0 & 4687.2 \\
\hline $\mathrm{DI} 2$ & 5136.0 & 4488.0 & 4368 & 4663.2 & 4411.2 & 4312.8 & 4272.0 & 4332.0 \\
\hline DI3 & 4392.0 & 3696.0 & 3480 & 3856.8 & 3907.2 & 3816.0 & 3552.0 & 3758.4 \\
\hline DI4 & 3768.0 & 3456.0 & 2760 & 3328.8 & 3763.2 & 3520.8 & 2880.0 & 3228.0 \\
\hline F(Mean) & 4675.2 & 4063.2 & 3775.2 & & 4370.4 & 4003.2 & 3748.8 & \\
\hline
\end{tabular}

Table ( 6) Contribution of water table $\left(\mathrm{m}^{3} \mathrm{ha}^{-1}\right.$.) for wheat crop during the two growing seasons $2012 / 2013$ and 2013/2014.

\begin{tabular}{|l|c|c|c|c|c|c|c|c|}
\hline \multirow{2}{*}{ Treatments } & \multicolumn{4}{|c|}{ season 2012/2013 } & \multicolumn{3}{c|}{ season 2013/2014 } \\
\cline { 2 - 9 } & F1 & F2 & F3 & I - Mean & F1 & F2 & F3 & I - Mean \\
\hline DI1 & 0 & 0 & 0 & 0 & 0 & 0 & 0 & 0 \\
\hline DI2 & 0 & 0 & 0 & 0 & 0 & 0 & 0 & 0 \\
\hline DI3 & 367.2 & 472.8 & 681.6 & 506.4 & 439.2 & 472.8 & 921.6 & 612.0 \\
\hline DI4 & 662.4 & 655.2 & 1020.0 & 780.0 & 604.8 & 655.2 & 996.0 & 751.2 \\
\hline F - Mean & 256.8 & 283.2 & 424.8 & & 261.6 & 283.2 & 480.0 & \\
\hline
\end{tabular}


El-Hadidi, E.M. et al. 
Table (7) Effect of deficit irrigation and wide furrow on grain and straw yield of wheat ( $\mathrm{kg} \mathrm{ha}^{-1}$.) during 2012/2013 growing season

\begin{tabular}{|c|c|c|c|c|c|c|c|c|}
\hline \multirow{2}{*}{ Treat. } & \multicolumn{4}{|c|}{ Grain yield 2012/2013 } & \multicolumn{4}{|c|}{ straw yield 2012/2013 } \\
\hline & Flat $\left(F_{1}\right)$ & $\begin{array}{c}\text { Furrow } \\
\left(F_{2}\right)\end{array}$ & $\operatorname{Bed}\left(F_{3}\right)$ & I-Mean & Flat $\left(F_{1}\right)$ & $\begin{array}{c}\text { Furrow } \\
\left(F_{2}\right)\end{array}$ & $\operatorname{Bed}\left(F_{3}\right)$ & I-Mean \\
\hline $\mathrm{DI}_{1}$ & $6480.0 \mathrm{a}$ & $6655.9 a$ & $7087.9 \mathrm{~b}$ & 6741.336 & $7864.0 \mathrm{a}$ & $8143.2 \mathrm{a}$ & $8664.0 \mathrm{~b}$ & 8223.7 \\
\hline $\mathrm{DI}_{2}$ & $6691.9 \mathrm{a}$ & $6907.9 \mathrm{a}$ & $8119.2 \mathrm{a}$ & 7231.992 & $8136.0 \mathrm{a}$ & $8444.0 \mathrm{a}$ & $9944.0 \mathrm{a}$ & 8841.3 \\
\hline $\mathrm{DI}_{3}$ & $5880.0 \mathrm{~b}$ & $6103.9 \mathrm{~b}$ & $7159.9 \mathrm{~b}$ & 6381.336 & $7206.0 \mathrm{~b}$ & $7456.0 \mathrm{~b}$ & $8752.0 \mathrm{~b}$ & 7804.5 \\
\hline $\mathrm{DI}_{4}$ & $5508.0 \mathrm{c}$ & $5556.0 \mathrm{c}$ & $6583.9 c$ & 5882.664 & $6741.0 \mathrm{c}$ & $6784.0 \mathrm{c}$ & $8048.0 \mathrm{c}$ & 7190.9 \\
\hline F- Mean & 6304.8 & 6306 & 7237.9 & 6561.504 & 7487 & 7706.8 & 8852.0 & 8014.1 \\
\hline Comparison & ans followe & $\begin{array}{l}\text { a common } \\
\text { LSD (5) LSD }\end{array}$ & $\begin{array}{l}\text { are not sign } \\
\text { S.E.D L }\end{array}$ & 5) LSD (1) & 110 & & & \\
\hline
\end{tabular}

Table (8) Effect of deficit irrigation and wide furrow on grain and straw yield of wheat $\left(\mathrm{kg} \mathrm{ha}^{-1}\right.$.) during 2013/2014 growing season

\begin{tabular}{|l|c|c|c|c|c|c|c|c|}
\hline \multirow{2}{*}{ Treatments } & \multicolumn{4}{|c|}{ Grain yield 2013/2014 } & \multicolumn{3}{c|}{ straw yield 2013/2014 } \\
\cline { 2 - 9 } & Flat $\left(\mathbf{F}_{\mathbf{1}}\right)$ & $\begin{array}{c}\text { Furrow } \\
\left(\mathbf{F}_{\mathbf{2}}\right)\end{array}$ & Bed $\left(\mathbf{F}_{\mathbf{3}}\right)$ & I-Mean & Flat $\left(\mathbf{F}_{\mathbf{1}}\right)$ & $\begin{array}{c}\text { Furrow } \\
\left(\mathbf{F}_{\mathbf{2}}\right)\end{array}$ & Bed $\left(\mathbf{F}_{\mathbf{3}}\right)$ & I-Mean \\
\hline $\mathrm{DI}_{1}$ & $7080.00 \mathrm{a}$ & $7320.00 \mathrm{a}$ & $7800.00 \mathrm{~b}$ & 7399.99 & $8850.24 \mathrm{a}$ & $9151.99 \mathrm{a}$ & $8850.24 \mathrm{a}$ & 9252.26 \\
\hline $\mathrm{DI}_{2}$ & $7327.99 \mathrm{a}$ & $7600.01 \mathrm{a}$ & $8935.99 \mathrm{a}$ & 7954.66 & $9157.44 \mathrm{a}$ & $9500.81 \mathrm{a}$ & $9157.44 \mathrm{a}$ & 9943.99 \\
\hline $\mathrm{DI}_{3}$ & $6475.92 \mathrm{~b}$ & $6712.01 \mathrm{~b}$ & $7872.00 \mathrm{~b}$ & 7020.00 & $8099.04 \mathrm{~b}$ & $8386.39 \mathrm{~b}$ & $8099.04 \mathrm{~b}$ & 8770.66 \\
\hline $\mathrm{DI}_{4}$ & $6055.99 \mathrm{c}$ & $6112.01 \mathrm{c}$ & $7240.01 \mathrm{c}$ & 6469.34 & $7579.20 \mathrm{c}$ & $7638.41 \mathrm{c}$ & $7579.20 \mathrm{c}$ & 8089.34 \\
\hline $\mathrm{F}-$ Mean & 6735.00 & 6936.00 & 7962.00 & 7210.99 & 8421.60 & 8669.40 & 9951.19 & 9014.06 \\
\hline
\end{tabular}

In a column, means followed by a common letter are not significantly

Comparison $\quad$ S.E.D LSD (5) LSD (1) S.E.D LSD (5) LSD (1)

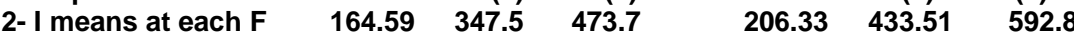


Table.(9a) Amounts of applied irrigation water, grain yield and water productivity (WPg) of wheat under different irrigation techniques in Egypt in 2012/2013 and 2013/2014.

\begin{tabular}{|c|c|c|c|c|c|c|c|c|c|c|c|}
\hline \multirow{2}{*}{\multicolumn{2}{|c|}{ Treatments }} & \multicolumn{10}{|c|}{ Season 2012/2013 } \\
\hline & & \multirow{2}{*}{$\begin{array}{c}\begin{array}{c}\text { Wa, } \\
\mathbf{m}^{3} / \mathbf{h a}\end{array} \\
6226\end{array}$} & \multirow{2}{*}{ 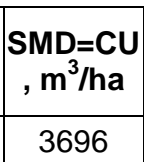 } & \multirow{2}{*}{\begin{tabular}{|c|}
$\begin{array}{c}E a= \\
\text { cu/wa*100 }\end{array}$ \\
59.37
\end{tabular}} & \multirow{2}{*}{$\begin{array}{c}\begin{array}{c}\text { Grain } \\
\text { yield } \\
\text { Kg/ha }\end{array} \\
7081.2\end{array}$} & \multirow{2}{*}{$\begin{array}{c}\begin{array}{c}\text { Straw } \\
\text { yield } \\
\text { Kg/ha. }\end{array} \\
7800\end{array}$} & \multirow{2}{*}{$\begin{array}{c}\text { L.E } \\
\text { grain /ha } \\
20252.23\end{array}$} & \multirow{2}{*}{$\begin{array}{c}\begin{array}{c}\text { WP } \\
\text { Grain } \\
\mathbf{k g} / \mathbf{m}^{3}\end{array} \\
1.10\end{array}$} & \multirow{2}{*}{$\begin{array}{c}\begin{array}{c}\text { IWP } \\
\text { Grain } \\
\text { kg/m }\end{array} \\
1.14\end{array}$} & \multirow{2}{*}{\begin{tabular}{|c|}
$\begin{array}{c}\text { WP } \\
\text { (L.E /m3) }\end{array}$ \\
5.45
\end{tabular}} & \multirow{2}{*}{$\begin{array}{c}\begin{array}{c}\text { IWP } \\
\text { (L.E /m3) }\end{array} \\
3.24\end{array}$} \\
\hline \multirow{4}{*}{$\frac{\overparen{0}}{\stackrel{+}{\frac{\pi}{4}}}$} & $\mathrm{DI}_{1}$ & & & & & & & & & & \\
\hline & $\mathrm{DI}_{2}$ & 5962 & 3600 & 60.39 & 7326.0 & 8400 & 20952.36 & 1.34 & 1.23 & 5.76 & 3.48 \\
\hline & $\mathrm{DI}_{3}$ & 5585 & 3552 & 63.60 & 6476.4 & 7200 & 18522.50 & 1.20 & 1.16 & 5.15 & 3.28 \\
\hline & $\mathrm{DI}_{4}$ & 5256 & 3408 & 64.84 & 6055.2 & 6600 & 17317.87 & 1.22 & 1.15 & 5.03 & 3.26 \\
\hline \multirow{4}{*}{ 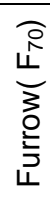 } & $\mathrm{DI}_{1}$ & 5434 & 3336 & 61.40 & 7318.8 & 8400 & 20931.77 & 1.35 & 1.35 & 6.21 & 3.81 \\
\hline & $\mathrm{DI}_{2}$ & 5314 & 3312 & 62.33 & 7599.6 & 8400 & 21734.86 & 1.41 & 1.43 & 6.49 & 4.04 \\
\hline & $\mathrm{DI}_{3}$ & 4994 & 3276 & 65.59 & 6710.4 & 7200 & \begin{tabular}{|l|l|}
19191.74 \\
\end{tabular} & 1.25 & 1.34 & 5.80 & 3.80 \\
\hline & $\mathrm{DI}_{4}$ & 4937 & 3264 & 66.12 & 6109.2 & 6600 & 17472.31 & 1.17 & 1.24 & 5.30 & 3.50 \\
\hline \multirow{4}{*}{ 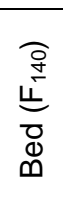 } & $\mathrm{DI}_{1}$ & 5314 & 3600 & 67.75 & 7801.2 & 8400 & 22311.43 & 1.46 & 1.47 & 6.12 & 4.15 \\
\hline & $\mathrm{DI}_{2}$ & 5194 & 3576 & 68.85 & 8935.2 & 9900 & 25554.67 & 1.68 & 1.72 & 5.14 & 3.54 \\
\hline & $\mathrm{DI}_{3}$ & 4987 & 3504 & 70.26 & 7873.2 & 9000 & 22517.35 & 1.42 & 1.58 & 6.36 & 4.47 \\
\hline & $\mathrm{DI}_{4}$ & 4606 & 3408 & 74.00 & 7239.6 & 7800 & 20705.26 & 1.47 & 1.57 & 6.01 & 4.45 \\
\hline
\end{tabular}


Table (9b)

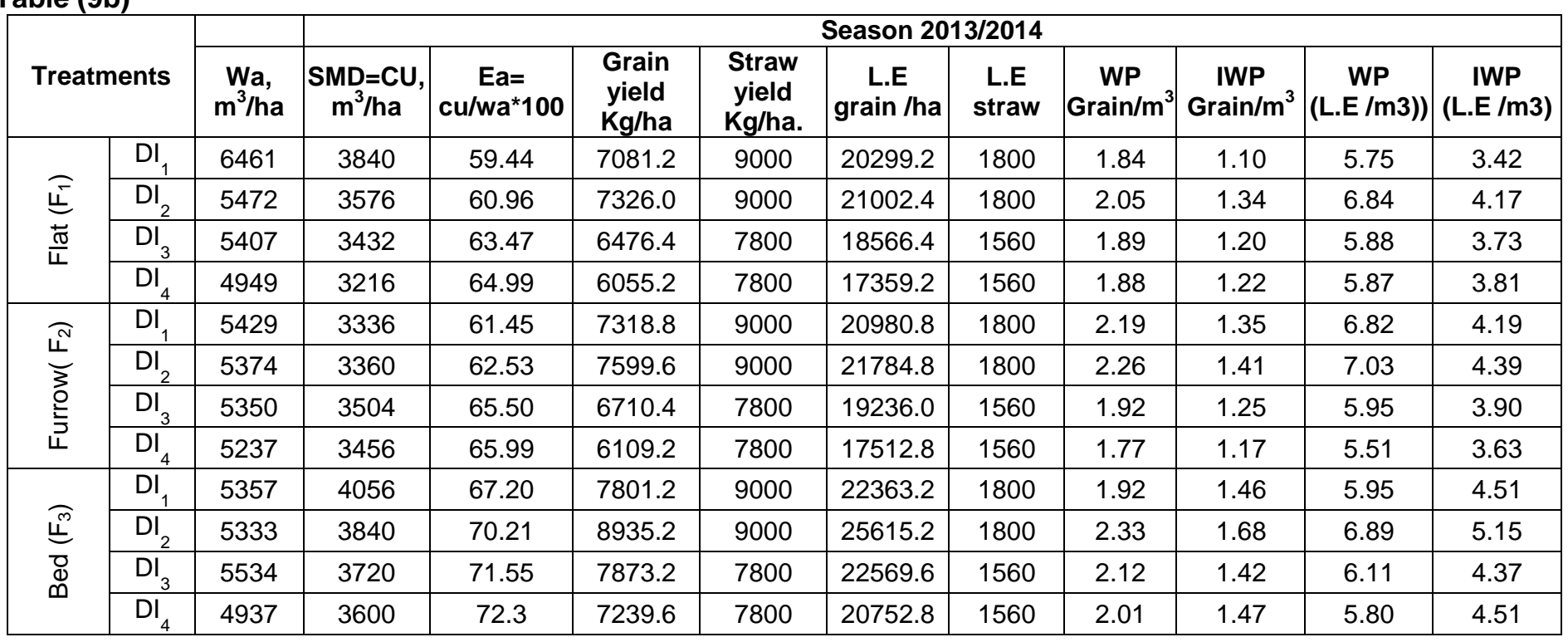


El-Hadidi, E.M. et al. 